\title{
Research at the RIBA: an institutional history 1958-1971
}

Article

Accepted Version

Hay, R., Shasore, N. and Samuel, F. (2017) Research at the RIBA: an institutional history 1958-1971. Architectural Research Quarterly, 21 (4). pp. 328-337. ISSN 1359-1355 doi: https://doi.org/10.1017/S135913551800012X Available at https://centaur.reading.ac.uk/74707/

It is advisable to refer to the publisher's version if you intend to cite from the work. See Guidance on citing.

To link to this article DOI: http://dx.doi.org/10.1017/S135913551800012X

Publisher: Cambridge University Press

All outputs in CentAUR are protected by Intellectual Property Rights law, including copyright law. Copyright and IPR is retained by the creators or other copyright holders. Terms and conditions for use of this material are defined in the End User Agreement.

\section{www.reading.ac.uk/centaur}

\section{CentAUR}

Central Archive at the University of Reading

Reading's research outputs online 
arq 21.4 - RESEARCH - AS - Pre-FINAL 03.01.18

Focussing on the development of research in the Royal Institute of British Architects, this paper makes the case for institutional history as a basis for future strategy.

\section{Research at the RIBA: An institutional history 1958-1971}

Rowena Hay, Neal Shasore and Flora Samuel

Exactly 50 years ago, the Council of the Royal Institute of British Architects (RIBA) launched a new policy and commitment to 'architectural research.' At its meeting on 7 December 1967, it set in motion a new programme to accelerate and coordinate the growth of research in architecture, not only in architectural schools, but through research centres and in practices. In addition, it reinforced its commitment to building up the Institute's own competence in research, 'so that it can speak authoritatively on behalf of the profession in the formulation of national research policies and investment programmes. ${ }^{1}$

This paper seeks to historicise the formation, development and promotion of architectural research - what we are terming the idea of architectural research - in light of the Institute's renewed commitment to a research agenda through the appointment in December 2017 of a Vice President for Research (an entirely new role) and the publication of a suite of resources aimed at 'de-mystifying' research in practice and promoting the evidencing of design quality and the value of the architect. These initiatives have their origin in the invention of architectural research as a distinct tradition and a post-rationalisation of what had gone before, following on from the Oxford Conference in 1958. Furthermore, we situate the invention of this tradition not only within professional and educational debates of the post-war period, but also in the changing and fluctuating landscape of government policy on the promotion and funding of research, itself a response to a perceived cultural and political angst about the UK's shortcomings in productivity and development. In contextualising and problematising the creation and fostering of a 'research culture' in the UK architecture profession over the last 60 or so years, we also uncover some of the assumptions behind the contemporary self-conscious pre-occupation with 
developing the research culture of architects. ${ }^{2}$ The paper begins with a discussion of historiography and methodology before moving to the research context of construction history and the role played by the RIBA Research Group in developing the idea of architectural research.

\section{Historiography and methodology}

This paper makes a case for the role that historians can play in unpacking the past as a precursor for future action. Our approach has been to view the idea of architectural research through the lens of institutional history. We have focussed primarily on architectural research as it pertains to practitioners many academics were also practitioners at that time - in order to give emphasis to wider industry and funding agendas. ${ }^{3}$

The bulk of our research initially took place in the RIBA's institutional archive. Despite some limitations, this is an unusually rich institutional record, which includes the records of the RIBA Research Group in the late 1960s and early 1970s, the focus of this paper. The Group was formed in 1967 initially under the aegis of the Board of Architectural Education, evolving from the Postgraduate Training and Research Committee formed in 1962. It came to an end in 1971 (at a time of deep recession) upon the formation of the RIBA Intelligence Unit, a body with a wider remit over policy and administration - territory into which this paper does not stray. Nevertheless, this rubbing-up of executive function with membership-led initiative, amid fairly regular restructuring at the RIBA, has clearly had significant implications for decision-making and corporate memory, which requires further research. The mid-1960s to the mid-'70s was a period in which members of the Research Group worked highly effectively with staff, and in which intellectual engagement with the the creation of a research tradition was particularly acute. These records consist of meeting minutes and secretarial reports authored mainly by Bill Hillier, known now as the progenitor of Space Syntax and then working at the RIBA [1], supplemented through an interview with Hillier himself.

To trace initiatives of this period backwards and forwards, we relied on the architectural press, predominantly the Journal of the Royal Institute of British Architects (RIBAJ), but also The Architects' Journal (AJ) for critical balance. The RIBAJ has been a particular focus because it of its status as the official publication of the RIBA. We observed discussions about research in the journal from 1958 with coverage of what is widely held to be the crucial conference in relation to contemporary discussions of research in architecture - The Oxford Conference - tracking debates started here through to the early 1970s.

It is, however, important to remember that even coverage by the RIBAJ is mediated, in particular in this period where the title underwent significant editorial reform. After Noel Musgrave (a former Editor of the Architects and Builders' Journal) stepped down as Editor in 1964, the RIBA Journal Committee updated its heavy-handed editorial policy, giving the journal a new remit and renewed editorial independence through its new editor, 
Malcolm MacEwen. MacEwen was clearly sympathetic to the research agenda (he helped to instigate and edit the Journal of Architectural Research), and to the importance of research and development more widely - our research has unearthed a number of pieces on these subjects in the 1960s and 1970s during his tenure, but care must be taken in discerning bias and the historian should, more importantly, look for deviations or questioning of Institute policy rather than seeing the Journal as a mere receptacle for it.

There are significant lacunae in the profession's corporate memory. We suggest that the institutional history of the RIBA - its committees, services and activities - provides a useful prism through which to examine broader professional themes as it highlights connections between protagonists which conventional monographic architectural history might fail to exploit.

Construction history provides one model for a more rounded understanding of the technical, political, economic and social aspects of building ${ }^{4}$ as have efforts in the architectural humanities, such as Katie Lloyd Thomas, Tilo Amhoff and Nick Beech's edited volume Industries of Architecture. 5 Though these historical analyses uncover intangible structures within the wider construction industry, they tend to focus still on processes leading to built forms, whereas the history of practice and professionalism (or rather, practices and professionalisms in the construction industry) may not do so directly.

The pioneering revisionist work of David Edgerton on the history of science and technology is useful here because architectural research at that time allied itself so closely to a scientific ideal. 'There is', he argues, 'a long tradition of characterising post-1870 Britain by its lack of enthusiasm for science and technology.'6 Increased investment in industrial research and development, by government and by industry, is presented as the solution to this anti-technological bias, irrespective of whether in fact investment in science and technology, and application in industry had indeed been happening in reality (which Edgerton demonstrates it had), and irrespective of Britain's actual decline in industrial productivity (properly relativised in its international context).

\section{Context}

The development of the practice of architecture in Britain has engaged with new technologies and scientific discoveries as well as more formal concerns in plan. section and elevation since the first emergence of the profession in the seventeenth century. Recent work on the early Royal Society and architectural experimentation as intellectual inquiry has provided greater clarity on this relationship. ${ }^{7}$ The main driver for development of the professions was sociotechnical change - new health requirements, new materials, new structural possibilities, new stylistic influences - caused by the advent of the industrial revolution. ${ }^{8}$ These required new forms of representation as well as new collective, and sometimes global, ways of working, particularly when servicing the commercial activities of Britain and its colonies. The 
architectural profession developed in a flurry of categorisation so characteristic of the Victorian era.

The Institute of British Architects first came into being in 1834. Its original prospectus makes its purpose clear - the advancement of the knowledge of architects [2]. It was not the first time that a group of architects had banded together for mutual support, but it was the most enduring association. ${ }^{9}$ Right from the very beginning there was pressure to define the architect's role vis-a-vis others who might have a claim on the territory. Andrew Saint writes that at that time 'the only element in architecture to which some other professional group did not have a prior or better claim, was "art"', a claim that was to make 'steady progress' over the years, particularly amongst the privately wealthy. ${ }^{10}$ H.S. Goodhart-Rendel observed in his 1933 book, The Professionals, 'Norman Shaw, himself a practical man as well as a great artist, wrote an essay with a title "That an Artist is not Necessarily Unpractical", and everybody agreed that he was not necessarily so with the inward reservation that more often than not he would be'. ${ }^{11}$ Norman Shaw's book Architecture as Profession or Art (1892), emblematic of this discussion, was to cause a rift between the two different parts of the nascent profession.

The origins of the technocratic view of architectural science and research, however, emerged with the advent of architectural Modernism in Britain in the 1930s, a critique which, as Edgerton has showed, tended to deny antecedents and parallel activities particularly if they were felt not to be politically progressive. As Saint has argued, in the first half of the twentieth century, the 'most popular and widespread manifestation of scientific thinking in architecture became the ideal of 'research.' ${ }^{2}$ He argues that it was, Berthold Lubetkin's Tecton Group which, founded in 1932, instituted architectural research as a 'self-conscious activity', then enthusiastically but somewhat emptily taken up by the Modern Architectural Research (MARS) Group, established the following year. Such initiatives were clearly influenced by the initiation of the Congrès Internationaux d'Architecture Moderne (CIAM) by Le Corbusier on the other side of the Channel. In the early 1950s the sensual, spiritual, symbolic and seemingly irrational curves of Le Corbusier's Chapel at Ronchamp caused a temporary wobble in the British profession's sense of direction best exemplified by James Stirling's famous essay on the 'crisis' of rationalism in architecture. ${ }^{13}$ When faced with such uncertainty, a growing call emerged for 'a scientific attitude towards design as a basis for a rich developing aesthetic', which could address fully the needs of people. ${ }^{14}$

Important protagonists of evidence-based and systems thinking (the clustering of data to inform decision making) were Leslie Martin and Lionel March at Cambridge University and Richard Llewelyn Davis at University College London, instigators of the 1958 Oxford Conference on Education, an attempt to place architecture within the academy of science based research. Martin's principles were absorbed into a wide range of initiatives still extant, for example the National Building Specification, defining and setting standards for construction. Even though their work was 'socially motivated 
and generous-spirited', Martin and Llewelyn Davis received loud criticism from influential and noisy quarters. ${ }^{15}$ Increasingly powerful critical theorists rallied against its elitism and essentialism, challenging its explicit hierarchies of professionals and inhabitants, and questioning both its tendency to treat individuals as 'users and the singular authority that it accorded to functional 'truths'.16

\section{Construction research}

In the early-to-mid twentieth century, research in the construction industry continued, largely oblivious to architectural fashion. In 1921, the Building Research Station was set up, one of a series of government research organisations aimed at bringing the benefits of applied science to industry, and a significant moment for formalising construction research. It began with experiments in traditional materials, such as stone and thatch, before moving on to geotechnical and structural engineering and then to the effect of bombs and explosions in WWII. Studies broadened-out to encompass building physics, lighting and acoustics (including human factors) in the post war years. ${ }^{17}$ The height of the effort was in 1947 when the Building Research Station (BRS) employed well over 300 people, although it slowed thereafter [3].

The post-World War II years are portrayed as a period when construction research 'enjoyed widespread and uncritical support', 18 and a pinnacle of research funding, ${ }^{19}$ as work was undertaken to facilitate the speed and economy of reconstruction. During this era there was a major push on Codes of Practice, standardisation and non-traditional forms of construction, resulting in the creation of New Directorates of Post-War Building and Building Materials within the portfolio of the Minister of Works - a dedicated ministry being indicative of the support given to construction and infrastructure at that time.

Research in the 1950s was focused largely on improving the functional relationship between space and activities, as well as the improved development of environment control. 'Each study was securely financed to its conclusion, and the pressures of the design/build process were taken off in the interests of careful testing of the proposed solutions' ${ }^{20}$ The experimental system-built Hertfordshire Schools Programme was, for example, financed by the Ministry of Education. ${ }^{21}$

Research in UK universities and specialised research institutions was largely been funded through government, most notably through the University Grants Committee ${ }^{22}$ and the Research Councils. Although research had been a priority during the Wars, it apparently lost ground as a strategic priority. ${ }^{23}$ In 1963, the National Joint Consultative Committee of Architects, Quantity Surveyors and Builders called a conference at Cambridge, 'representative of the whole building industry', ${ }^{24}$ and the outcome was a plan to establish a basis, on an industry wide scale, for 'The Building Industry Communications Research Project' with funds drawn almost equally from industry and government sources. Led by the Tavistock Institute, its primary 
intellectual aim, according to Frank Duffy, was to develop theory in the context of practice. ${ }^{25}$ The two year project ran out of money along the way but not before it had come to two conclusions. Firstly that if the building industry is to reach the degree of efficiency it should attain [...] not only [...] greater co-operation between its various indispensable elements, but that cooperation must be based on knowledge and not merely on hunches' ${ }^{26}$ The second question, which remains unanswered, was how this 'long term fundamental research' was to be paid for. Striking a similar tone, the RIBA presented evidence to the Heyworth Committee on Social Studies (1965-71) arguing that there was an urgent need for the establishment of a Research Council for the Built Environment to coordinate disparate research activities in the sector. ${ }^{27}$

This was also a time when the major Research Councils were reconstituted or came into being. The Social Science Research Committee (SSRC) was a result of the Heywood Committee on Social Studies, appointed by Rab Butler in 1963 to 'review the research at present being done in the field of social studies in Government departments, universities and other institutions and to advise whether changes are needed in the arrangements for supporting and coordinating this research.' ${ }^{28}$ As Desmond King has argued, the 'decision to found a designated research council for social science was a correlate of the postwar consensus in which social democrats and others believed social problems could be alleviated through planning'. 'A major stimulus for the Heyworth Committee's creation', King reflects, 'was the assumption that potential users of research - aside from government were not receiving sufficient information.' ${ }^{29}$ The discussions of the Committee, interestingly, were 'inextricably linked with its role in public policy application'. ${ }^{30}$

The Committee took evidence from the RIBA, who recommended the establishment of a built environment research council. As well as recommending the formation of what became the SSRC, Heyworth's report made recommendations pertaining to the built environment. A Research Council for Planning or the Built Environment required research that 'involves technology, the physical sciences and the arts equally with the social sciences disciplines.' 31 Though this field required 'special and urgent attention' in the words of the Committee, they could not recommend an entirely new research council which 'would exacerbate the problems of communication.' ${ }^{32}$ Instead, they proposed a 'Joint Board,' initially under the sponsorship of the SSRC to investigate the issue further and the RIBA remained pursuant of this idea or the proposal for a more substantial research council until the early 1970s.

\section{The Ministry and its committees}

Meanwhile, in the early 1960s, the reformulated Ministry of Public Buildings and Works (MPBW) began to take an active role in research and development in the field of construction. Within the Ministry itself, a new DirectorateGeneral of Research and Development was formed in 1964, headed by 
veteran local authority architect, Sir Donald Gibson. Coincidentally, this was also the year that Gibson became President of the RIBA and it is perhaps therefore no surprise that interest in government activity in research and development began to trickle down into practice at this point. Three years later, the Building Research Station was brought within the MPBW's purview through financial control, though it remained otherwise largely autonomous. Three other significant bodies were also set up this time: the Construction Research Advisory Council, the Construction Industry Research and Information Association, and the Centre for Environmental Studies.

The Construction Research Advisory Council (CRAC) was directly linked to the MPBW, and was indeed chaired by Anthony Part, Permanent Secretary to the ministry. Acknowledging the fractious and fragmentary nature of the industry, its remit was 'To survey the national need for construction research, to review existing facilities, to consider measures necessary to encourage the expansion and more effective deployment of available resources, and to advise on the dissemination of research results.' 33 The Council included Gibson, Stirrat Johnson-Marshall, Llewelyn-Davies, the Chief Architect to the Ministry of Health and the Chief Scientific Advisor to the Cabinet Office among others.

The Construction Industry Research and Information Association (CIRIA) was a research organisation grant-aided by the new Ministry of Technology, and was a successor to the Civil Engineering Research Organisation (CERA). It was established to provide a research service for its members in building and civil engineering, and an information and advisory service for the wider industry. It had originally been intended by Geoffrey Rippon, then Minister of Public Buildings and Works, that CIRIA would be funded by a compulsory industry-wide levy supplemented by government aid. In the end this proposal was rejected by industry, and CIRIA was funded by voluntary membership with a pound-for-pound grant from the Ministry of Technology, and a further pound-for-pound grant for the MPBW for expenditure on the information service. Established in 1966, by 1969 its Director (incidentally a member of CRAC) was reporting to the MPBW that it lacked sufficient financial support from industry and needed further funding from government. The RIBA had warned that, because of its voluntary membership, it would struggle to expand its resources easily to service the wider industry fully. After the National Consultative Council for the Building and Civil Engineering Industries (NCC) once again resisted the idea of the industry levy, CIRIA abandoned its general information and advisory activities, and focussed on meeting the needs of its members (around 600 bodies of civil engineers, contractors, local authorities and public agencies) 'undertaking little work directly with its own staff but generally placing contracts with other research associations, universities and the industry.'34

Finally, the Centre for Environmental Studies (CES) was an independent education trust promoting research in the physical environment funded by the Ford Foundation and the UK Government. Administered by a governing body of ten people, the chair - Llewelyn-Davies - was appointed 
by the Minster of Housing and Local Government, and its board initially also included the architect-planner William Holford. Its work began around April 1967, and it immediately began to define a research policy and programme for research in the environmental field to be undertaken by internal staff and other sponsored groups.

This was the backdrop for the creation of the new RIBA Research Group. Perhaps perversely, it was against a background of governmental focus on construction industry research that new ideas about the distinctiveness of architectural research began gaining new prominence in architectural discourse and at the RIBA. However, even in the late 1960s it was still unclear which group or individual was chiefly responsible for steering RIBA policy in this area. Relationships with CIRIA and CRAC, and the overarching policy of research financing was felt to rest with Council advised by the Policy Committee, and government bodies were dealt with directly by the President or an appointed Vice President. In 1962, the Postgraduate Teaching and Research Committee was constituted by the RIBA Board of Education, which in 1967 was renamed the Research Committee (still under the Board of Education) before later transmuting into the RIBA Research Steering Group under the presidency of Alex Gordon.

\section{The RIBA Research Committee}

This section discusses the practical activities and programme of the RIBA Research Committee, but also traces the intellectual development of the idea of research by Committee members and their wider networks.

The Research Committee undertook a number of activities in the late 1960s and early 1970s. In terms of policy, through their overlapping membership with board members of other construction industry research bodies, the group remained hopeful either of a built environment research committee or an inter-council board set up for architectural/built environment research as suggested by the Heyworth Committee. There was a concern that, under the arrangements as they emerged, architectural or built environment research applications tended to 'fall between committees or pass to unsympathetic people.' 35 There was a hope that the Centre for Environmental Studies would be sympathetic to architectural research. It was chaired by Llewelyn-Davies and was connected to the group through UCL Professor of Engineering, Henry Chilver, later Lord Chilver, who incidentally went on to become Chair of the Universities Funding Council and a champion of applied research. The group was in fact more interested in environmental and city scale and planning than it was in architecture. This is perhaps reflected in Llewelyn-Davies's practice's shift towards planning, encapsulated by his move from the Chair of Architecture at UCL to the Chair of Planning in 1969, replacing William Holford.

Early aspirations to form a Research Policy Group, perhaps an attempt to move away from the ad hoc nature of Council decisions in this area, never gained any traction. Nevertheless, policy and sources of research finance remained a standing item on the Committee's agenda. Papers were circulated, for instance, on formulating a long-term policy 'to establish a unified source 
of finance for research in the built environment.' ${ }^{36}$ There was felt to be 'something of a crisis, or least a crossroads' in this regard by 1968. Bill Hillier was concerned that research-financing bodies were developing funding policies without any 'specific commitment to architectural research,' as the CES had done. ${ }^{37}$ It was resolved to make meaningful contact with appropriate bodies - relations with the SSRC were strong though informal, while the purpose of CIRIA remained somewhat elusive. Around this time, Thomas Markus presented a paper on the nature of architectural research, arguing for 'a growing need for an adequate model of the whole field of research in the built environment.' 38 By July, he put forward a paper to the group which postulated how to sub-divide research in the built environment, possibly through levels of scale (discarded because of the propensity to territorialism by different professional bodies), but more likely through research into 'goalsystems, decision systems and productive systems' each of which 'involve certain central disciplines and have many common features, irrespective of the scale at which the systems operate.' 39

The Research Committee had a consistent interest in the research capacity of schools of architecture. Regular schools visits were undertaken to this end, with a view to compiling a report surveying architectural research to help in the fostering of relationships with research councils. Members wanted to ensure that new researchers were coming through the ranks, not just architectural graduates but also specialists coming in from other disciplines.

In 1965, the RIBA conducted a survey of research in schools of architecture the results of which 'could then be summarised on a single sheet of paper' ${ }^{40}$ The Journal of Architectural Research and Teaching [4] was set up to correct this situation, to provide an outlet for university-located research and facilitate the 'application of research findings to design practice and teaching' ${ }^{41}$ It was nominally edited by Geoffrey Broadbent with Malcolm McEwen, but initially championed by F.M. Jones and Bill Hillier. Despite collaboration with US partners and a lavish launch party at the American Embassy [5] its existence was brief, a sorry reflection on 'the ability of researchers, practitioners and educators themselves to sustain a high level of constructive discourse, criticism and collaboration in improving the knowledge base of their work' ${ }^{42}$

By 1969, there was still felt to be a 'Changing Situation' as one paper presented to the Committee put it. ${ }^{43}$ The SRC had established a Building Design Sub-Panel reporting to its Aeronautical and Civil Engineering Committee to advise on grants and policies. Chaired by Markus, its scope was to think - rowing back slightly on his report of the previous year - about architecture at a number of scales, from building groups, to individual buildings, to interiors and down to fixtures and fittings. Though research 'at the hardware end' was felt to be within the purview of the SRC, psychological and sociological studies fell within the remit of the SSRC. The Sub-panel suggested that it might be constituted as this bridging committee, and the title of the Aeronautical and Civil Engineering Committee be changed to reflect this broader remit. ${ }^{44}$ 
In the early 1970s, so far as the archival record of the Committee shows, corroborated through the pages of RIBAJ, the debate about what precisely constituted architectural research had started to intensify, resulting in a loose degree of coalescence. The technocratic assumptions of the late 1950s and 1960s began to be challenged, or at least thought through more critically, and the assumption of the continued existence of a large public sector with government supported and funded research and development was no longer as strong as it had been in the preceding decade.

The seeds of criticism of the Oxford Conference reforms gained increasing momentum, particularly the re-assertion of a concern with creativity and imagination in design as much as systems and process, coupled with a growing frustration from some corners of the profession with the scientific and theoretical drift of discourse. A write-up of a RIBA symposium focusing on education for research, for instance, reflected vocal resistance from some delegates to embedding research methods and 'fundamental research' into undergraduate architecture courses. ${ }^{45} \mathrm{An}$ article reporting on a panel of practitioners considering the future of architectural education acknowledged a 'general view' that the educational reforms following the Oxford Conference, which had focused on academic achievement rather than creative flair, had been a 'disaster' for the profession. ${ }^{46}$ There was, as a result, a reframing of research in this context and a recognition of the need to expand research interests beyond just that which was quantifiably 'measurable' .47 There was a criticism of the dominance of scientific rationality and the focus on building technologies, materials and efficiencies now seen as reductive because of its failure to capture the complex interrelationships between buildings, people and environment and results in a dehumanised building process. ${ }^{48}$ In this context, there was continuing and growing embrace of the methods of the social sciences with their emphasis on diversity and complexity, and an acceptance of a pluralist and more uncertain world. ${ }^{49}$

Proponents of research also highlighted the importance of a robust evidence base so that architects could prove their worth: 'architecture matters because it affects everybody's life'. And there was an ever-pressing need to improve 'understanding of our skills, and capability and of the service we could provide to the public. ${ }^{50}$ This was seen as particularly important at a time when the profession appeared to be losing ground to other specialists ${ }^{51}$ and came under attack from the monopolies commission. In this context, there was a need to focus research on 'real people' and 'real buildings' 52 whilst also addressing the 'widening gap' between the schools and practice to ensure that research knowledge and best-practice was properly shared). ${ }^{53}$ The RIBA was beginning to take more seriously the role of linking-up practice with research - with a focus on environmental issues - through Alex Gordon's long-life, loose-fit, low-energy study, the point at which the research group was wound up. ${ }^{54}$

\section{Conclusion}


The archives of the RIBA Research Group reveal the diminution in public sector architecture research in the UK even before Margaret Thatcher came to power in 1979, bringing with her the dissolution of local authority architects across the UK (a process that is currently being reversed in the field of housing). The shift back towards private interests and practice, along with the narrowing of public sector agenda nonetheless reignited the argument that architecture needed to be conceived of as a 'social service'. ${ }^{55}$

Cut backs as result of recession saw the marginalisation of the RIBA's research function. ${ }^{56}$ The departure of Bill Hillier and Adrian Leaman in the mid-1970s deprived the Institute of vital corporate memory and intellectual clout in driving forward a more critical idea of architectural research.

Research advocates complained that RIBA Council's neglect of its original research-informed learned society role was curtailing serious debate about the nature of professionalism,, 57 and that undue emphasis was being given to professional status and elitism. ${ }^{58}$ The result of such changes was a shift away from evidencing the value of architecture through long-term research towards image and marketing: 'the emphasis will be on the image of the architect's creativity and how it can better be utilised in this period of change'. ${ }^{59}$

In this paper, we have described how the RIBA Research Committee of the Board of Education tried to gain some foothold in the shifting policy landscape of research funding within the realpolitik of chronic underinvestment in research in the wider construction industry. ${ }^{60}$ During this period, it became apparent that, to get the ear of policy makers, it was necessary to define the distinctive nature of architectural research and the boundaries of a body of knowledge over which architects might claim prime custody, an idea that Frank Duffy was to develop through his work on 'architectural knowledge' and through a series of strategies for the RIBA, including a space use study by his practice, DEGW, in the 1980s. ${ }^{61}$ This architectural knowledge, arguably distinct from, say, building or materials research, was predicated on the socio-technological aspects of spaces - mainly enclosed spaces - and the understanding of activity and environment within the building envelope. This was the epistemological underpinning of building performance, and one that sought to preserve the perceived intellectual supremacy of the designer, rather than, say, the builder. Questions of professional identity and value thus underpinned the institutional history of architectural research. These questions remain just as relevant and urgent now as they were in the 1970s, and piecing this history together helps us to formulate them carefully for today.

\section{References}

1 RIBA, 'A new RIBA policy for research and architecture', The Journal of the Royal Institute of British Architects, 74 (1967), 50-51.

2 Flora Samuel, 'Supporting Research in Practice', Journal of Architecture, 22:1 (2017), 1-10. 
3 See Alan Powers, 'The Fiction of Architectural Education' in Harriet Harriss and Daisy Froud (eds.), Radical Pedagogies (Newcastle: RIBA, 2015), p. 4 for an excellent discussion of architectural education.

4 See for instance, articles in the journal Construction History, founded by Mark Swenarton, such as E.W. Cooney, 'Innovations and contracts in the Post-War Building Industry', Construction History, 3 (1987); E.W. Cooney, 'Innovation in the Post-War Building Industry: A Historical Review'; E.W. Cooney, 'Productivity, Conflict and Order in the British Construction Industry: A Historical Review', 9 (1993); G. Atkinson, 'Thoughts During the Building Research Establishment's 75 th Anniversary, 12 (1996); and Mark Swenarton, 'Breeze Blocks and Bolshevism: Housing Policy and the Origins of the Building Research Station, 1917-1921', 21 (2005/6).

${ }^{5}$ Katie Lloyd Thomas, Tilo Amhoff and Nick Beech (eds.), Industries of Architecture (London: Routledge, 2016).

${ }^{6}$ David Edgerton, Science and Technology and the British Industrial 'Decline', 1870-1970 (Cambridge: Cambridge University Press, 1996), p.1.

7 See for instance the work of Matthew Walker, especially Matthew Walker, Architects and Intellectual Culture in Post-Restoration England (Oxford: Oxford University Press, 2017).

8 J. Wilton-Ely, 'The Rise of the Professional Architect in England', in S. Kostof (ed.), The Architect (Berkeley: University of California Press, 1977), p.195.

${ }^{9}$ Gotch, J.A. (ed.), The Growth and Work of the Royal Institute of British Architects. (London: Simson and Co Ltd, 1934).

${ }^{10}$ A. Saint, The Image of the Architect (New Haven: Yale University Press, 1983), p.61.

${ }^{11}$ Quoted in B. Kaye, The Development of the Architectural Profession in Britain A Sociological Study (London: Allen and Unwin, 1960).

12 Andrew Saint, Towards a Social Architecture: The Role of School-Building in Post-War England (New Haven, London: Yale University Press, 1987), p.11 13 J. Stirling, 'Ronchamp: Le Corbusier's Chapel and the Crisis of Rationalism', Architectural Review, 119, March (1956), 155-161.

14 Cox, O., 'Method in Design', Plan: Architectural Association Students Journal, 4 (1949), 17-18.

15 Adam Sharr and Stephen Thornton, Demolishing Whitehall: Leslie Martin, Harold Wilson and the Architecture of White Heat (Farnham: Ashgate, 2013), p.198.

16 Adam Sharr, 'Leslie Martin and the Science of Architectural Form', in: Dutoit, A., Odgers, J., Sharr, A. (eds.), Quality out of Control: Standards for Measuring Architecture (London: Routledge, 2010), p.68.

17 R. Courtney, 'Building Research Establishment: Past, Present and Future', Building Research and Information, 25:5 (1997), 285-91.

18 P.R. Lansley,'The Impact of BRE's Commercialisation on the Research Community', Building Research and Information, 25:5 (1997), 301-312.

19 J. Darke and R. Darke, Who Needs Housing? (London: Macmillan, 1979), p.134 
20 J. Musgrove, J., P. O'Sullivan, C. Territ, B. Hillier and A. Leaman,

'Architectural Research: Problems of Organization and Funding in the United Kingdom', Journal of Architectural Research, 4 (1975), 41.

${ }^{21}$ M.P. Keath, 'The development of school construction systems in

Hertfordshire 1946-1964', Unpublished PhD thesis Thames Polytechnic, 1973.

Available online at:

http://gala.gre.ac.uk/8740/1/Michael_P._K._Keath_1983.pdf [accessed 15.12.17].

22 P. Manning, 'Hard Facts on Research', Architects Journal, 20 January (1965),

194.

23 Musgrove et al., 'Architectural Research', 41-43.

24 Tavistock Institute, Interdependence and Uncertainty (Digest of a report from the Tavistock Institute to the Building Industry Communication Resarch Project).

(London: Tavistock Institution, 1966), p.13.

${ }^{25}$ F. Duffy, 'Forum Linking theory Back to Practice', Building Research and Information, 36:6 (2008), pp.657.

26 Tavistock Institute, 1966. Interdependence and Uncertainty (Digest of a report

from the Tavistock Institute to the Building Industry Communication Resarch

Project). (London: Tavistock Institution,1966), p.ix.

27 RIBA Drawings and Archives Collection, Institutional Archive, Research

Committee Minutes and Papers (1967-1971), Secretary's Report for meeting 24

April 1968 (dated 10 April 1968).

28 Report of the Committee on Social Studies (London: HMSO, 1965), p.1

(hereafter 'Heyworth Committee Report'). For a full account of the

establishment and activities of the Social Science Research Council see

Desmond King, 'Creating a Funding Regime for Social Research in Britain:

The Heyworth Committee on Social Studies and the Founding of the Social

Science Research Council', Minerva, 35 (1997), pp.1-26.

${ }^{29}$ King, 'Creating a Funding Regime for Social Research in Britain', p.19.

30 Ibid., p.11.

${ }^{31}$ Heyworth Committee Report, pp.48.

32 Ibid., p.49

${ }^{33}$ RIBA Drawings and Archives Collection, Institutional Archive, Research

Committee Minutes and Papers (1967-1971), Memorandum entitled 'Board of

Education - Research Committee - Construction Research Advisory Council'

(undated).

34 RIBA Drawings and Archives Collection, Institutional Archive, Research

Committee Minutes and Papers (1967-1971), Report entitled 'Extracts form the

Fourth Report from the Estimates Committee Session 1967-68' (1968).

35 RIBA Drawings and Archives Collection, Institutional Archive, Research

Committee Minutes and Papers (1967-1971), Memorandum entitled 'RIBA

Research Awards Scheme: Report to Schools' (undated)

${ }^{36}$ RIBA Drawings and Archives Collection, Institutional Archive, Research

Committee Minutes and Papers (1967-1971), Research Committee Minutes (24 April 1968).

37 Ibid. 
38 Ibid.

39 Ibid.

40 G. Broadbent, B. Hillier, A. Lipman, R. MacLeod, L. Musgrove, P.

O'Sullivan, B. Wilson, 'Editorial', Architectural Research and Teaching, 1 (1970),

p.3.

41 Ibid.

42 Musgrove et al., 'Architectural Research', pp.41-43.

${ }^{43}$ RIBA Drawings and Archives Collection, Institutional Archive, Research Committee Minutes and Papers (1967-1971), Report entitled 'Funding and Organisation of Architectural Research' appended to Secretary's Report (30 April 1969).

44 RIBA Drawings and Archives Collection, Institutional Archive, Research Committee Minutes and Papers (1967-1971), Paper entitled 'Report of the Built Environment and its Users - Sub-Panel', appended to Secretary's Report (29 January 1969).

45 R. Macleod 'RIBA Symposium: Education for Research', Journal of the Royal Institute of British Architects, Volume 76 (1969), 51.

46 RIBA, 'The Making of an Architect', Journal of the Royal Institute of British Architects, 85 (1978), 79.

47 A. Macmillan, 'Architects are also People', Journal of the Royal Institute of British Architects, 78 (1971), 451.

${ }^{48}$ H. Skolmowki,. 'Rationality in Architecture', Journal of the Royal Institute of British Architects, 79 (1972), pp.330-333; J. Musgrove, 'SCAN: Technology and People', Journal of the Royal Institute of British Architects, 79 (1972), 350.

${ }^{49}$ R. Llewelyn Davies, 'The Tuscan Artist: Thought and Action in Design', Journal of the Royal Institute of British Architects, 83 (1976), 352.

50 E. Lyons, 'Architecture - The Social Art', Journal of the Royal Institute of British Architects, 83 (1976), 3-4.

${ }^{51}$ A. Derbyshire, 'Preparing for the Eighties,' Journal of the Royal Institute of British Architects, 76 (1969), pp.66.

52 J. Musgrove, 'SCAN: From the USA', Journal of the Royal Institute of British Architects, 78 (1971), 517.

53 RIBA, 'Widening Gap?', Journal of the Royal Institute of British Architects, 78 (1971), 91; A. Meikle, 'Education and Practice', Journal of the Royal Institute of British Architects, 77 (1971), 199; J. Musgrove, 'SCAN: Knowing and Doing', Journal of the Royal Institute of British Architects, 78 (1971), 86.

${ }^{5}$ A. Gordon, 'Presidential Address: Alex Gordon: Architecture: For Love or Money?', Journal of the Royal Institute of British Architects, 78 (1971), 537.

${ }_{55}$ M. MacEwen, 'Malcolm MacEwen on the Professional Dilemma', Journal of the Royal Institute of British Architects, 78 (1971), pp.191; W. Lathaby, 'Education of the Architect', Journal of the Royal Institute of British Architects, 80 (1973), 580.

56 RIBA, 'Pruning can be Fruitful', Journal of the Royal Institute of British Architects, 10 (1975), 20.

${ }^{57}$ M. MacEwen, 'MacEwen's Crisis in Architecture: The Times have

Changed', Journal of the Royal Institute of British Architects, 10 (1975), 24. 
${ }^{58}$ P. Malpass, 'Professionalism and the Role of Architects in Local Authority Housing,' Journal of the Royal Institute of British Architects, 10 (1975), 29.

${ }^{59}$ RIBA, 'RIBA Conference 1976: Architecture, Opportunity, Achievement', Journal of the Royal Institute of British Architects, 83 (1976), 87.

${ }^{60}$ C. Powell, The British Building Industry since 1800: An Economic History (London: Routledge, 2013), p.179.

${ }^{61}$ F. Duffy, Strategic Study of the Profession, Phases $3 \&$ 4: The Way Forward (London: RIBA, 1995). The 1981 DEGW space use study for the RIBA Headquarters at 66 Portland Place is in the Special Collections at the University of Reading.

\section{Illustration credits}

arq gratefully acknowledges:

((please add copyright holder information here))

\section{Author's biographies}

Rowena Hay is a social researcher specialising in housing and built environment research. She has a decade of experience managing research projects and evaluations across the public, voluntary and higher education sectors including the House of Lords, the CIC, CABE, Durham University and the University of Reading. She is currently research director at ShortWork, working on a diverse portfolio of research including an evaluation of the social and economic impact of investment in built environment heritage in Hull, research into the links between inclusive design and disability sport participation in Sheffield, and the development of a network of paid community researchers to inform local planning in Tower Hamlets.

Neal Shasore is...

Flora Samuel is the first Vice President for Research at the RIBA and Professor of Architecture in the Built Environment at the University of Reading and was formerly Head of the University of Sheffield School of Architecture. She has published exstensively on Le Corbusier, a process that led her to reflect on the purpose and value of architectural practice. Her forthcoming book Why Architects Matter: Evidencing and Communicating the Value of Architects will be published by Routledge in April 2018 , the product of three Arts and Humanities Research Council grants on supporting the development of research in practice.

\section{Author's addresses}

Rowena Hay

hay.misty@gmail.com

Neal Shasore

neal.shasore@googlemail.com 
Flora Samuel

f.b.samuel@reading.ac.uk

\section{CAPTIONS}

1. Bill Hillier

2. Prospectus for the Institute of Architects

3. Building Research Station

4. Journal of Architectural Research and Teaching

5. Joint reception between the RIBA and the AIA on Tuesday 23 April 1974 at the American Embassy in London to celebrate their joint collaboration on the Journal of Architectural Research.

\section{WEB ABSTRACT}

Exactly 50 years ago, the Council of the Royal Institute of British Architects (RIBA) launched a new policy and commitment to 'architectural research.' At its meeting on 7 December 1967, it set in motion a new programme to accelerate and coordinate the growth of research in architecture, not only in architectural schools but through research centres and in practices. In addition, it reinforced its commitment to building up the Institute's own competence in research, 'so that it can speak authoritatively on behalf of the profession in the formulation of national research policies and investment programmes.

This paper seeks to historicise the formation, development and promotion of architectural research - what we are terming the idea of architectural research - in light of the Institute's renewed commitment to a research agenda through the appointment in December 2017 of a Vice President for Research (an entirely new role) and the publication of a suite of resources aimed at 'de-mystifying' research in practice and promoting the evidencing of design quality and the value of the architect. These initiatives have their origin in the invention of architectural research as a distinct tradition and a post-rationalisation of what had gone before following on from the Oxford Conference in 1958. Furthermore, we situate the invention of this tradition not only within professional and educational debates of the post-war period, but also in the changing and fluctuating landscape of government policy on the promotion and funding of research, itself a response to a perceived cultural and political angst about the UK's shortcomings in productivity and development. In contextualising and problematising the creation and fostering of a 'research culture' in the UK architecture profession over the last 60 or so years, we also uncover some of the assumptions behind the contemporary self-conscious pre-occupation with developing the research culture of architects. The paper begins with a discussion of historiography and methodology before moving to the research 
context of construction history and the role played by the RIBA Research Group in developing the idea of architectural research. 